business and public administration school - in São Paulo, Michael Gibbons, director of the Science Policy Research Unit at the UK University of Sussex, summarized the situation by pointing out that "the scientific, technological and educational developments established in the 1970 s no longer seem to be working".

The three papers indicate that the main reason is economic. Most of the major institutions associated with the development of a robust national scientific and technological capability - in particular government research establishments and universities are in financial difficulty, and their links with industry remain weak.

There is a general consensus that the private sector should do more to support science. Only 15 per cent of the country's bill for research and development is paid by the private sector, compared to around 70 per cent in some Asian countries such as Taiwan, Korea and Japan.

Yet how to attain the competitiveness of the Asian 'tigers' remains hotly debated. Many at the Getlio Vargas meeting felt that this could still be achieved through State backing for basic science.

But others pointed out that India, for example, is a Third World country that has invested heavily in science with only limited results in terms of economic development; they suggested instead that Brazil copy the market-driven, low-to-high-tech approach of countries such as Taiwan and South Korea.

Whichever path is taken, one hurdle remains: the antiquated Brazilian state. Any science and technology policy requires a stable economy, if it is to be successful, and in the case of Brazil this may need long-term reform of the state.

Brazil still lacks a unified science policy. Ivan Rocha, of the University of Brasilia, who participated in Biato's study, says that science funding agencies need to link science to broader industrial and educational goals; otherwise funding agencies will continue "shooting in all directions", he says.

The next government will have to deal with the big projects of the past, including schemes for a nuclear submarine, military aircraft and a space rocket launcher. Military research still accounts for one-fifth of the government's spending on research.

Some are demanding reductions in such spending. But others, such as Geraldo Lesbat Cavagnari Filho, a former Army colonel, who is now a researcher at Unicamp, says the government should finish what has already been started.

Cavagnari has given this advice to the presidential candidate now second in public opinion pools, Luiz Incio Lula da Silva, of the left-wing Workers Party (Partido dos Trabalhadores). Many scientists may not like it. But, as Cavagnari says, they have much to lose, as 90 per cent of the armed forces' researchers are civilians.

Ricardo Bonalume Neto

\title{
Koop may set up new centre for alternative medicine
}

Washington. Joseph Jacobs, who steps down in October as head of the Office of Alternative Medicine at the US National Institutes of Health (NIH), may be about to join forces with C. Everett Koop, the outspoken surgeon general in the Reagan administration, in setting up a centre for alternative medicine at Dartmouth Medical College in New Hampshire.

The Koop Institute at the college promotes curriculum changes in medical schools. David Serra, a co-director of the institute, confirmed rumours that Koop was having discussions with Jacobs but refused to say about what. He did say that if such a centre went ahead its aim would be to investigate alternative therapies with the assumption that some regimens work. But, he added, "we can't get too far ahead of ourselves because there is some opposition within Dartmouth".

Jacobs and Koop both believe that primary care could play a greater role in health care in the United States (see Nature 370, 501 ; 1994). Jacobs, who is reticent about his future plans, says that it is in this context that he would like to see alternative medicine given more serious attention.

Jacobs has had a rough ride as the first head of the Office of Alternative Medicine, which was established by a congressional mandate to further research into practices such as acupuncture and herbalism. Colleagues say that he has been caught between the traditional biomedical community and extremists in alternative medicine.

"My critics at both ends of the spectrum are caught in a mind set of 20 years ago," says Jacobs. "A way forward for alternative medicine is through primary health care. The critics and zealots don't really understand that. They are in a political battle and are using the NIH as a battlefield," he added.

Jacobs believes that the Office of Alternative Medicine should not be attached to the National Institutes of Health, which he says is a "highly specialized, quintessential research organization" that is not suited to the more mundane research needed in alternative medicine. Nevertheless, he believes that to dismiss conventional medicine is narrow-minded. Like many at the centre of the debate, Jacobs would be more comfortable if alternative medicine were called complementary medicine (as it is in much of Europe).

Steve Martin, assistant professor of medicine and of the history and philosophy of medicine at the Albert Einstein
College of Medicine in New York, says, "the term alternative medicine encompasses a wide array of techniques, some compatible with conventional medicine, some not".

If Koop and Jacobs do establish a centre for alternative and complementary medicine at Dartmouth, they will join a small

IMAGE
UNAVAILABLE
FOR
COPYRIGHT
REASONS
group of respected medical schools, such as Harvard and Columbia, that have set up similar centres within the past year or so.

In fact, a paper published in the New England Journal of Medicine last year by

Acupuncture gains credibility as an alternative therapy. David Eisenberg, who established Harvard's centre, has provided some of the impetus behind the increasing interest of medical students and faculty in alternative practices. Eisenberg concluded from a telephone survey that, in 1990, Americans spent about US\$13.7 billion on alternative therapies.

One of the most widely used of these alternative therapies was acupuncture. The Office of Alternative Medicine has collected data from clinical trials that lawyers representing acupuncturists were to present this week as part of a petition to have acupuncture needles removed from the Food and Drug Administration's (FDA)'s list of investigational devices.

Investigational devices should be used only experimentally, but, in practice, acupuncture needles are widely used for treatment. James Turner, the lawyer presenting the petition, expects a decision from the FDA within the next six months. If acupuncture needles are taken from the list of investigational needles, it will be possible for patients to reclaim the cost of treatment from federal programmes that pay for the health care of the elderly and the poor.

The next item on the agenda of the Office of Alternative Medicine is to persuade the FDA to allow some clinical trials of Chinese herbs. One application was submitted by Freddie Kronenberg, a physiologist who heads Columbia's centre for alternative and complementary medicine. She wants to investigate the effectiveness of Chinese herbs for the relief of hot flushes during the menopause.

Helen Gavaghan 